\title{
Systematic layout planning of wineries: the case of Rioja region (Spain)
}

\author{
Javier Gómez, ${ }^{1,2}$ Alberto Tascón, ${ }^{2}$ Francisco Ayuga ${ }^{3}$ \\ ${ }^{1}$ Faber 1900, Logroño; ${ }^{2}$ Department of Agriculture and Food, University of La Rioja; ${ }^{3}$ Department of Agroforestry \\ Engineering, Polytechnic University of Madrid, Spain
}

\begin{abstract}
Winery design can be very varied - the consequence of different influences acting at different times of construction. Unlike the designs of other food industries, those of wineries are commonly influenced by aesthetics - sometimes to potentiate wine tourism, and sometimes to safeguard the agricultural landscape of which they are part. However, the functionality of the production space cannot be ignored; the efficient distribution of space in a winery contributes towards both economic and environmental sustainability - two requisites of an ever more demanding and competitive market. The present work gathers qualitative and quantitative information on the design of industrial wineries in Spain's Rioja winemaking region. Different classes of winery are identified and, using the systematic layout planning method, several type layouts proposed. With the necessary adaptations made to suit particular circumstances, these could be used to guide future winery design in the same and other winemaking areas.
\end{abstract}

\section{Introduction}

Wineries are food industries of very varied design, the outcome of the influence of conditioning factors such as the type of product to be made, the site and its orientation and surroundings, climatic conditions, the architectural design of the building and its desired aesthetic effect, relationships with other economic activi-

Correspondence: Alberto Tascón, Department of Agriculture and Food, Universidad de La Rioja, Av. Madre de Dios 51, 26006 Logroño, Spain. Tel.: +34.941299733.

E-mail: alberto.tascon@unirioja.es

Key words: Design; plant layout; Rioja wine; winery.

Contributions: the authors contributed equally.

Conflict of interests: the authors declare no potential conflict of interests.

Received for publication: 30 August 2017.

Accepted for publication: 2 November 2017.

CCopyright J. Gómez et al., 2018

Licensee PAGEPress, Italy

Journal of Agricultural Engineering 2018; XLIX:778

doi:10.4081/jae.2018.778

This article is distributed under the terms of the Creative Commons Attribution Noncommercial License (by-nc 4.0) which permits any noncommercial use, distribution, and reproduction in any medium, provided the original author(s) and source are credited. ties, the construction materials available, and the investment made (Jacquet, 1999). Recent decades have seen the appearance of further influences, such as the appropriate management of waste and its associated installations (Catalano, 1999), fire protection and health and safety requirements (Storm, 1997), and the protection of the environment and landscape (Jeong et al., 2012; Tassinari et al., 2013). These new conditioning factors can vary greatly between countries and even regions of the same country. The technical requirements requested by oenologists - which are often winery-specific - can also influence the overall design, as can the quality-associated conditions for designations of origin and geographical indications protected in the EU (European Commission, 2017).

Although the alcohol, polyphenols and $\mathrm{pH}$ of wine generally prevent the growth of any pathogenic microorganisms that might be present (Martínez-Rodríguez and Carrascosa, 2009), winery design and layout must incorporate basic principles of hygiene (Institut Technique de la Vigne et du Vin, 2013). Also, winery design must take into account that bottling rooms are particularly sensitive to aerial contamination (Donnelly, 1977).

In recent years, the architectural component of winery design has been enhanced as a means of attracting attention, often with wine tourism in mind (Stanwick and Fowlow, 2006). A number of wineries of architectural note - some designed by renowned architects - have appeared across the world. However, these designs should not ignore the functionality of the production space, i.e. the need to make wine, and the need (sometimes) to age it.

The optimisation of the layout of manufacturing systems has been an active area of research for decades (Vollmann and Buffa, 1966) and continues to be of great interest (Huang and Wong, 2017), but few studies have specifically looked at food industry facilities (Van Donk and Gaalman, 2004). This is particularly true for wineries. Torreggiani et al. (2014) reported on the design of farm wineries in the Italian region of Emilia-Romagna, but the particular characteristics and small size of these wineries make it difficult to extrapolate any findings to other regions and industrial buildings.

The winery layout can have an important influence on running costs, wine quality, and the safety of the winemaking process. The importance of defining the necessary design criteria for different types of winery has taken on greater importance of late given the need to marry technical requirements with economic and environmental sustainability, and the need to make headway in a market ever more competitive and demanding in terms of quality (Martin and Canas, 2006; Torreggiani et al., 2013; Barbaresi et al., 2017a, 2017b). Certainly, the analysis of the energy costs and other environmental impacts associated with wine production, and their minimization, is of growing interest worldwide (Herath et al., 2013; Rugani et al., 2013). An appropriate plant layout design can therefore be understood as the first step in contributing towards such economic and environmental sustainability.

Spain's Rioja winemaking area - Rioja Qualified Designation of Origin or Rioja QDO (Denominación de Origen Calificada 
Rioja or DOCa Rioja) - contains some 61,870 ha of vineyards (Control Board of the Rioja Designation of Origin, 2016) and is one of the oldest and most prestigious in the country. The importance of winemaking to the regional economy is huge: nearly 177 million litres of wine made here enter the Spanish market, and around 107 million litres enter the international market, with the UK, Germany and the USA the biggest importers (Control Board of the Rioja Designation of Origin, 2016). The wine sector accounts for $21 \%$ of the region's gross product and directly employs some 14,000 people (Larreina et al., 2011).

The aim of the present work was to gather qualitative and quantitative information on the design of the industrial and cooperative Rioja wineries, and to extract therefrom criteria that might help optimise the design of new wineries for both the Rioja region and other winemaking areas of similar characteristics.

\section{Methodology}

\section{Sampling of wineries}

Information was gathered on 62 industrial and cooperatives wineries in the Rioja wine region. The selection of wineries was not random; rather the sample included those willing or able to share information. The Rioja area is home to 594 wineries registered as bottlers; 390 of these perform ageing, 54 are storage wineries, 27 are cooperatives, and 123 are traditional farm wineries that do not perform ageing (Control Board of the Rioja Designation of Origin, 2016). The traditional farm wineries, which were not included in the present study, are small wineries of viticulturists who prepare wine from their own grapes to later sell it, usually without performing ageing; this type of Rioja winery was traditionally named bodega de cosechero. The storage wineries were also excluded since they do not possess the normal production areas of most wineries; their efforts centre on the marketing of wines produced by other wineries. The total number of wineries originally eligible for sampling was therefore 417 . The $62(14.9 \%)$ sampled included $14.4 \%$ of the wineries that undertake ageing (56 wineries), and $22.2 \%$ of the cooperatives ( 6 wineries). The total production capacity of these wineries is some 1.79 million $\mathrm{hL}$ $\left(0.179\right.$ million $\left.\mathrm{m}^{3}\right)$ - around $59.9 \%$ of the 2.99 million $\mathrm{hL}$ of Rioja wine produced in 2015 (Control Board of the Rioja Designation of Origin, 2016).

Information on the wineries was collected during the authors' professional work, from winery representatives, from other engineers and designers, from technical publications, and during visits planned specifically for this purpose. The layout of each winery was obtained either on paper or in digital format; all were eventually digitalized in CAD. Survey forms were designed to make the collected data uniform and comparable. The information collected was structured around 20 variables (some qualitative, some quantitative) that would allow design criteria and parameters to be analysed: i) location; ii) activity; iii) total area occupied $>2500 \mathrm{~m}^{2}$ (yes/no); iv) unconventional design (yes/no); v) year of construction; vi) ageing (yes/no); vii) number of wood barrels (if question vi affirmative); viii) production $(\mathrm{hL})$; ix) total built area $\left(\mathrm{m}^{2}\right) ; \mathrm{x}$ ) production area $\left(\mathrm{m}^{2}\right)$; xi) wine storage area $\left(\mathrm{m}^{2}\right)$; xii) area given over to oenological treatments $\left(\mathrm{m}^{2}\right)$; xiii) area for ageing in barrels $\left(\mathrm{m}^{2}\right)$; xiv) area for ageing in bottles $\left(\mathrm{m}^{2}\right)$; $\left.\mathrm{xv}\right)$ bottling area $\left(\mathrm{m}^{2}\right)$; $\mathrm{xvi})$ area occupied by auxiliary industrial equipment $\left(\mathrm{m}^{2}\right)$; xvii) storage area $\left(\mathrm{m}^{2}\right)$; xviii) services (offices, laboratories, etc.) area $\left(\mathrm{m}^{2}\right)$; xix) social area $\left.\left(\mathrm{m}^{2}\right) ; \mathrm{xx}\right)$ area occupied by passageways $\left(\mathrm{m}^{2}\right)$. The variables related to surface areas (variables $x$ - $x x$ ) were selected from the analysis of the winemaking process and the subsequent identification of functional units, which are explained in detail in Sections Quantitative variables and Functional units. Indeed, these variables correspond with the functional units identified in Rioja wineries and used in the present study. In contrast, the selection of variables $i$-ix was based on the authors' experience and on previous knowledge of the Rioja wine sector (López and Gómez, 2008).

\section{Qualitative variables}

The first six of the above variables (location, activity, total area occupied $>2500 \mathrm{~m}^{2}$, unconventional design, year of construction, and ageing) are qualitative and help define the type of winery, its activity and main characteristics. With respect to variable $i i$ (activity), wineries may undertake a range of activities including production, ageing, bottling and storage. They only undertake those activities for which they are registered. Each type of activity has its own needs and requires its own designed space.

Variable iii (total area occupied $>2500 \mathrm{~m}^{2}$ ) establishes a dichotomy based on the $2400 \mathrm{~m}^{2}$ limit allowed by the regional government legislation for wineries built on non-urbanised land (here increased to $2500 \mathrm{~m}^{2}$ to allow for digitalization and layout plan errors).

Variable iv (unconventional design, yes/no) was included in the list of variables in order to identify those industrial wineries that presented characteristics that could potentially have distorted the data set and the subsequent layout designs. The identification of these atypical wineries followed a qualitative approach: the information and plant layouts collected were assessed by the authors to identify design singularities. For example, some wineries were designed to accommodate leisure activities, since the wine and leisure industries in the Rioja region are closely connected. Such wineries usually conduct tours, but some of them even include museums or spaces for weddings and other social gatherings. In addition, some designs were specifically aimed at attracting consumers to the winery and building a strong brand identity. In this respect, a number of remarkable wineries have been erected in the Rioja region (Stanwick and Fowlow, 2006). Although these winery design approaches probably increased the initial building costs, this does not necessarily imply that the resulting designs jeopardised the functionality and efficiency of the winemaking process areas. Another group of unconventional wineries are those that may have undergone successive expansions and adaptations; the final result would thus be very different from the original building but also from how a winery of a similar size would be planned today. Other design singularities are irregular layouts, wineries with large wine storage areas in absence of a production area (i.e., a winery that ages wines produced in other wineries), and wineries established in buildings originally designed for another purpose.

\section{Quantitative variables}

Variables vii- $x x$ are all quantitative. Variable vii (number of wood barrels) and viii (production) help characterize the winery in an overall manner, while $i x-x x$ (total built area, production area, wine storage area, area for oenological treatments, area for ageing in barrels, area for ageing in bottles, bottling area, area for auxiliary industrial equipment, storage area, services area, social area, and area occupied by passageways) do so with respect to the different operations carried out in the winery and its layout.

The different parts of the wineries were identified following the study by Torreggiani et al. (2011) with modifications when necessary. Figures 1 and 2 outline the different winemaking pro- 
cesses for Rioja wines and identified the sequence of operations, which were used as a guide (red wine is around $89 \%$ of the annual production of Rioja wine). Not all operations are performed at all wineries. The space requirements therefore differ, depending on whether red or white wine is made, whether it is marketed as young or aged, etc. Small variations in the sequence of operations may also be required by a winery's oenologists. As can be seen in Table 1, the winemaking process was divided into two macrophases corresponding to two functional macroareas: i) transformation, i.e., all operations related to wine production and ageing; and ii) support and commercialisation, including all actions related to quality control, health and safety, hygiene, and the marketing of the final product. These functional macroareas were divided into various functional units, normally separated by physical partitions. These functional units are where sets of interrelated operations with similar requirements or conditions are performed. However, each functional unit can have several functional areas, each represented in a physical space where a particular activity is best per-

Table 1. Winery functional units and the operations/functions undertaken in each.

\begin{tabular}{|c|c|c|}
\hline Macroarea & Functional unit & Operation/Function \\
\hline Transformation & Production & $\begin{array}{l}\text { Weighing and sampling } \\
\text { Unloading } \\
\text { Selection } \\
\text { Destemming and crushing } \\
\text { Sulphiting and corrections } \\
\text { Placing in vats } \\
\text { Alcoholic fermentation } \\
\text { Pressing } \\
\text { Maceration } \\
\text { Malolactic fermentation } \\
\text { Devatting } \\
\text { Removal of residues }\end{array}$ \\
\hline Transformation & Wine storage & Wine storage \\
\hline Transformation & Oenological treatments & $\begin{array}{l}\text { Inertisation } \\
\text { Clarification } \\
\text { Stabilisation } \\
\text { Filtration } \\
\text { Classification and homogenisation }\end{array}$ \\
\hline Transformation & Ageing in barrels & Ageing \\
\hline Transformation & Ageing in bottles & Ageing \\
\hline Transformation & Bottling & $\begin{array}{l}\text { Bottle washing } \\
\text { Filling and corking } \\
\text { Labelling } \\
\text { Packing } \\
\text { Placing on pallets }\end{array}$ \\
\hline Transformation & Industrial equipment & Auxiliary winemaking installations \\
\hline Transformation & Storage & $\begin{array}{l}\text { Storage of final product } \\
\text { Storage of auxiliary materials } \\
\text { Shipping }\end{array}$ \\
\hline $\begin{array}{l}\text { Support \& } \\
\text { commercialisation }\end{array}$ & Services & $\begin{array}{l}\text { Changing rooms, } \\
\text { showers } \\
\text { Toilets } \\
\text { Laboratories } \\
\text { Rest area }\end{array}$ \\
\hline $\begin{array}{l}\text { Support \& } \\
\text { commercialisation }\end{array}$ & Social area & $\begin{array}{l}\text { Offices } \\
\text { Shop } \\
\text { Tasting room }\end{array}$ \\
\hline $\begin{array}{l}\text { Support \& } \\
\text { commercialisation }\end{array}$ & Passageways & $\begin{array}{l}\text { Product movement } \\
\text { Visitors movement }\end{array}$ \\
\hline
\end{tabular}

formed, or where several but temporally or spatially connected activities are performed. The set of activities performed in the different functional areas together cover the wine production process.

\section{Functional units}

Table 1 shows the functional units usually found in Rioja wineries. Also, some of these units are indicated in Figures 1 and 2 . The production functional unit includes all operations involving the receipt of the grapes, the obtention of the must, and its transformation into wine.

The wine storage functional unit includes large tanks, even larger than the fermentation vats. This functional unit has a support relationship with those of production, oenological treatments, bottling and ageing. Wine is stored here until moving to the barrel

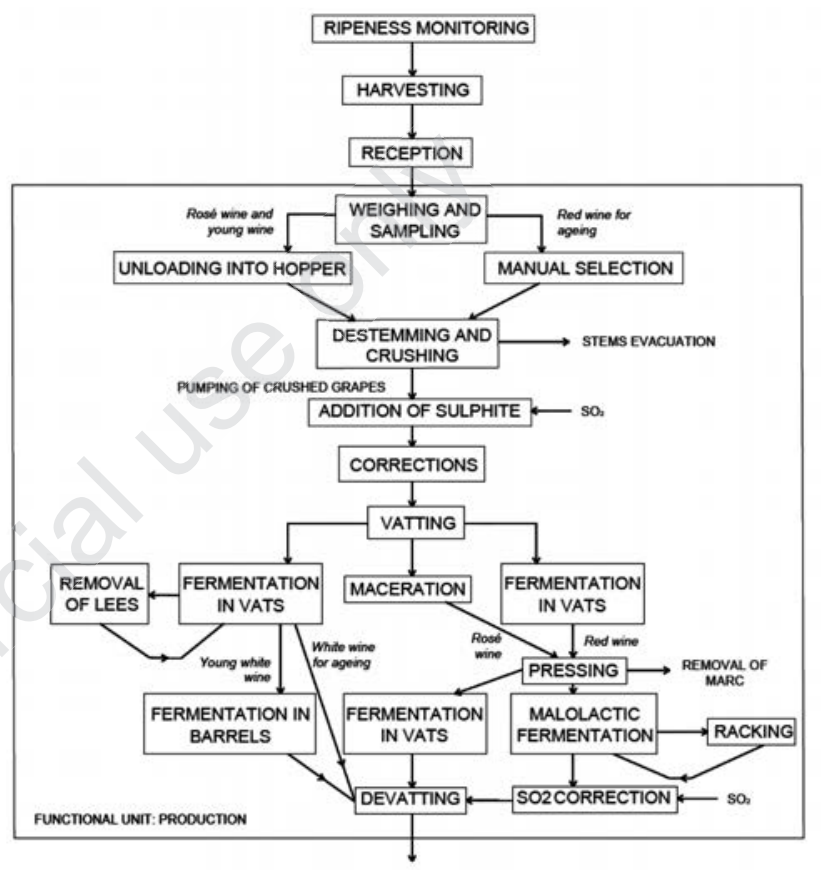

Figure 1. The Rioja wine production process (part I).

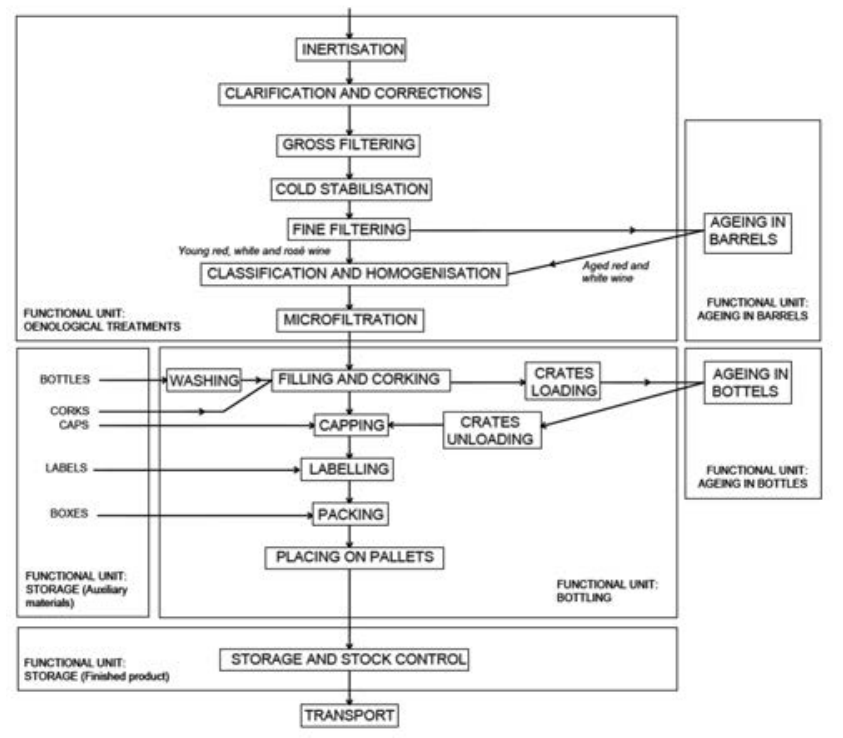

Figure 2. The Rioja wine production process (part II). 
washing and filling area (if the wine is to be aged) for subsequent ageing and oenological treatments. In addition, some wineries buy wine in bulk from cooperatives and place it in the above large tanks, or take it from these tanks to sell it in bulk to yet other wineries. Small wineries may not have this functional unit, however, and store wine in the production functional unit.

The oenological treatments functional unit is where wine classification, stabilisation, filtration and conditioning operations are performed. It may have many installations and is usually avoided in tourist visits. In some wineries, however, these operations are performed in the space of the wine storage unit.

The ageing in barrels functional unit receives wine from the production, oenological treatments or wine storage units, where it will be left to age for the appropriate time. This functional unit is a typical characteristic of the Rioja wineries. All but young Rioja wines (those of the grape production year) undergo some ageing in wood barrels.

The ageing in bottles functional unit is similar to that of the above unit. Indeed, some wineries perform both operations in the same space, although they are quite separate parts of the overall winemaking process. Bottles of wine, normally in crates, come to this area from the bottling area.

The bottling functional unit varies widely from one winery to the next. Some may have small, semi-automatic bottling areas, while others have large bottling plants. Until 2016 it was illegal to use mobile bottling stations in the Rioja winemaking region; while this will probably affect the design of new wineries, it could have had no influence on those studied in the present work. Rioja wineries with no bottling unit have always been able to request others with such capacity to carry out the process for them - but this had to be made clear on the label and was therefore usually avoided. In contrast, third party bottling is common across other parts of the world. In small wineries it is common for the bottling process not to have its own space; rather, it is performed where the final product will be stored, although isolated from it by some form of partition.

The industrial equipment functional unit may occupy one or several spaces where the auxiliary installations necessary for the winery to function are sited (e.g., steam vats, compressed air equipment, air conditioning, water treatment units, etc.). Most of these installations are subject to specific regulations.

The storage functional unit covers the storage of materials required for bottling and labelling, as well as the final product (classified by lot and destination). Sometimes these functions occupy separate spaces, but more commonly they are undertaken in one and the same. In large wineries, this space will usually have specially designed loading docks.

The services functional unit is home to a winery's laboratories and the spaces used by workers. The social area is one where no production functions are performed, and includes tasting rooms, sales points, bars and restaurants, meeting rooms, etc. This area is a relevant component of most tourist visits, and has taken on ever more importance in winery design with the rise of wine tourism.

The passageways functional unit provides connections between different areas involved in production that avoid having to pass through them. They are also used in visits, allowing the winery to be seen in a manner that does not interfere with its routine functioning.

\section{Analysis of winery layouts}

Layout can be defined as the arrangement of the processing stages to different spaces, and the interaction between these spaces (Van Donk and Gaalman, 2004). One of the best-known means of determining this arrangement is the systematic layout planning
(SLP) method developed by Muther (1961). Although a number of different approaches can be followed, Muther's method is one of the most frequently used methodologies for determining plant layout design (Liggett, 2000).

The SLP method addresses flows of goods, people and equipment between different spaces and between an industrial plant and its suppliers or clients, as well as the qualitative factors related to the different types of interaction between spaces. This information is presented in the form of a triangular matrix (the relationship diagram), which represents the demands of closeness or farness for each pair of spaces. Such demands are denoted by a set of letters, ranging from A (absolutely necessary closeness) to E (especially important), I (important), O (ordinary), U (unimportant) and X (not desirable closeness). In a second step, a space-relationship diagram is built up from the information on the space required and/or available for each unit, and the relationships shown in the previous relationship diagram. The final output is a block layout, which specifies the relative location of each unit and its size.

In the present work, the SLP method was followed making use of the winemaking process diagram in Figures 1 and 2 and the list of functional units in Table 1, but excluding passageways. Closeness/farness relationships between the functional units were determined bearing in mind the need to maintain the continuity of the winemaking process, but also taking into account hygiene and product quality criteria (necessary when using this method in a food industry setting) (Van Dock and Gaalman, 2004). Other features taken into account were noise emissions, smells, accessibility, health and safety, and the difference between dry and wet areas. To obtain the final block layout, the surface areas necessary for each functional unit were determined from the sample of wineries, considering mean values for each type of winery.

\section{Results and discussion}

The study of variables ii (activity), iii (total area occupied $<$ or $>2500 \mathrm{~m}^{2}$ ), iv (unconventional design), and $i x$ (total built area), allowed the sampled wineries to be arranged into four classes:

- Class A wineries: cooperatives. These generally make wine to sell in bulk to other wineries. The mean area given over to ageing is therefore small, and the wines made are little promoted. These factors influence their design, leaving these wineries in a class of their own.

- Class $B$ wineries: industrial scale wineries. These have a rational layout and generally undertake wine production, ageing and bottling. In the specific case of the Rioja winemaking area, these wineries can be further divided into two subclasses: those with a total area under $2500 \mathrm{~m}^{2}$ (Class B-1), and those with an area over $2500 \mathrm{~m}^{2}$ (Class B-2).

- Class $C$ wineries: unconventional industrial wineries. The design is not only based on the functionality of the space required for undertaking the winemaking processes, but also on other criteria. In some cases, the offer of leisure activities and the desired aesthetics may have been a major objective. In others, successive expansions and adaptations have led to a somewhat irrational layout. In yet others it can be the result of a winery being established in a building originally designed for another purpose. Class $C$ wineries are related to variable $i v$ (unconventional design, yes/no) and are usually large (over $2500 \mathrm{~m}^{2}$ ). The establishment of such wineries as distinct from those of Class B prevents them distorting the results of the latter wineries. 
The 62 wineries analysed in the present study were classified as follows: 6 Class $A$ wineries, 29 Class B-1, 12 Class B-2, and 15 Class $C$.

Figure 3 shows the layout of one of the Class $B-1$ wineries examined, including the different functional units identified. It is important to remark that the quantitative variables related to the size of the different functional units varied greatly across the different wineries; indeed, some did not have all the functional units described above. The most commonly missing were the wine storage, industrial equipment and oenological treatments functional units, which were present in only $13 \%, 13 \%$ and $11 \%$ of the inspected wineries respectively.

Table 2 shows the mean percentage surface area (with respect to winery total surface area) devoted to each functional unit for each winery class. The mean total surface area occupied by the Class $A$ wineries was $3569 \mathrm{~m}^{2}$, by the Class $B-1$ wineries it was $1458 \mathrm{~m}^{2}$, by Class $B-24991 \mathrm{~m}^{2}$, and by Class $C 13,240 \mathrm{~m}^{2}$.

In the Class $A$ wineries, the largest functional unit was that of production. This is explained in that cooperatives are primarily devoted to processing their members' grapes and not to ageing. The large wineries in Class $B-2$ and Class $C$ had the largest spaces devoted to ageing in barrels and bottles. It is remarkable that the mean surface area devoted to ageing in barrels in the Class $C$ wineries was larger than the mean value corresponding to the production functional unit. The reason for this might be twofold: first, the main product of most Class $C$ wineries consists of aged wine, which requires long ageing periods in wood barrels (minimum time of 12 months for Crianza red wine or 24 months for Gran Reserva red wine, according to the Rioja wine regulations) and thus large ageing rooms; second, several Class $C$ wineries - those wineries of outstanding design linked with leisure activities - usually present large ageing rooms that were not sized according only to the ageing process and the barrel stacking system selected, but also considering the visitors and the desired aesthetics and emotional values.

The area given over to the functional units wine storage and oenological treatments was found to be proportionally very large for Class $C$ wineries. This might be explained by the importance given by these wineries to wine tourism and the separation of these areas of eminently industrial appearance from tour itineraries. In smaller wineries, these functional units may still be integrated into areas where tourists pass by. The Class $C$ wineries were also those with the largest space given over to passageways - again reflecting the importance of guided visits.

Table 2. Mean percentage (\%) surface area devoted to each functional unit with respect to winery total surface area for each winery class.

\begin{tabular}{lcccc} 
Functional unit & Class A & Class B-1 & Class B-2 & Class C \\
Production & 59 & 35 & 38 & 20 \\
Wine storage & 0 & 1 & 1 & 7 \\
\hline Oenological treatments & 0 & 2 & 0 & 4 \\
Ageing in barrels & 11 & 25 & 31 & 22 \\
\hline Ageing in bottles & 8 & 3 & 5 & 13 \\
Bottling & 3 & 6 & 3 & 9 \\
\hline Industrial equipment & 0 & 1 & 0 & 1 \\
Storage & 1 & 6 & 6 & 10 \\
\hline Services & 1 & 2 & 1 & 1 \\
Social area & 16 & 16 & 14 & 11 \\
\hline Passageways & 1 & 4 & 1 & 2 \\
\hline
\end{tabular}

Figure 4 shows the SLP relationship diagram for Class $C$ wineries. The functional units for the relationship diagrams were selected considering the mean surface area values (Table 2), the number of wineries of each class that had these functional units, and also the authors' experience in winery design.

The diagram shown in Figure 4 was the only one that included the wine storage, oenological treatments and industrial equipment functional units, i.e. it included all the functional units excepting
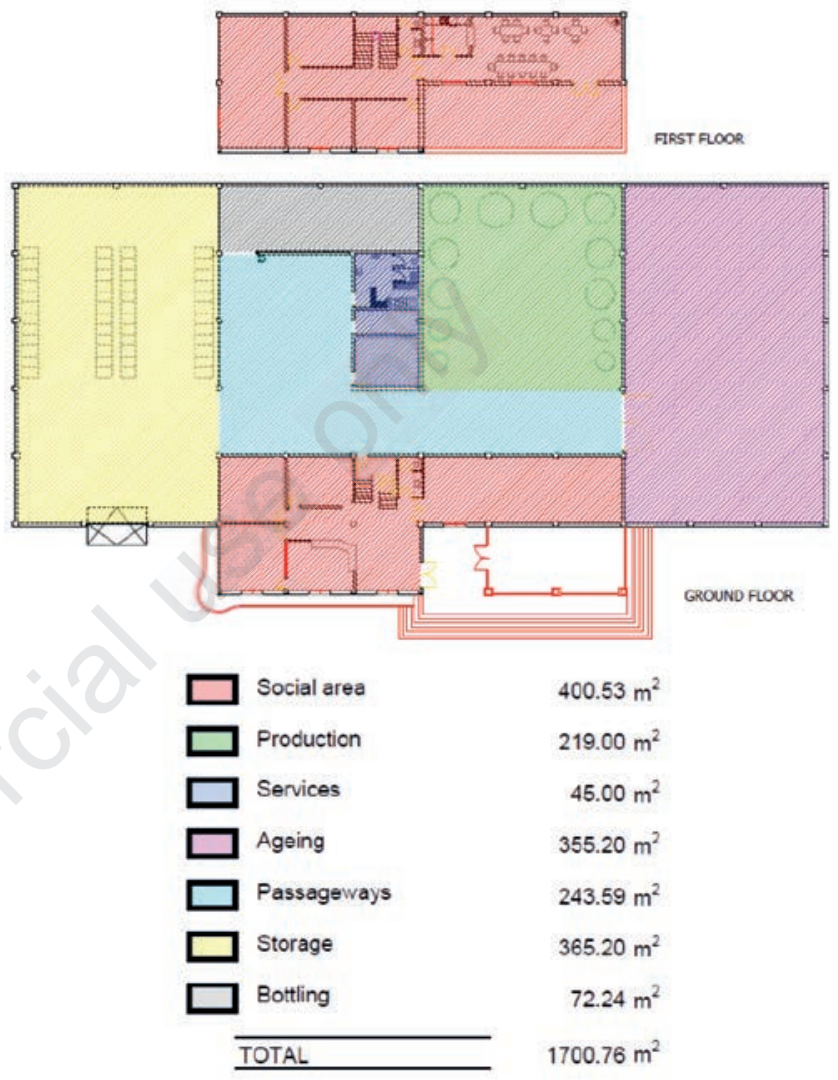

Figure 3. Class B-1 winery layout showing area given over to different functional units.

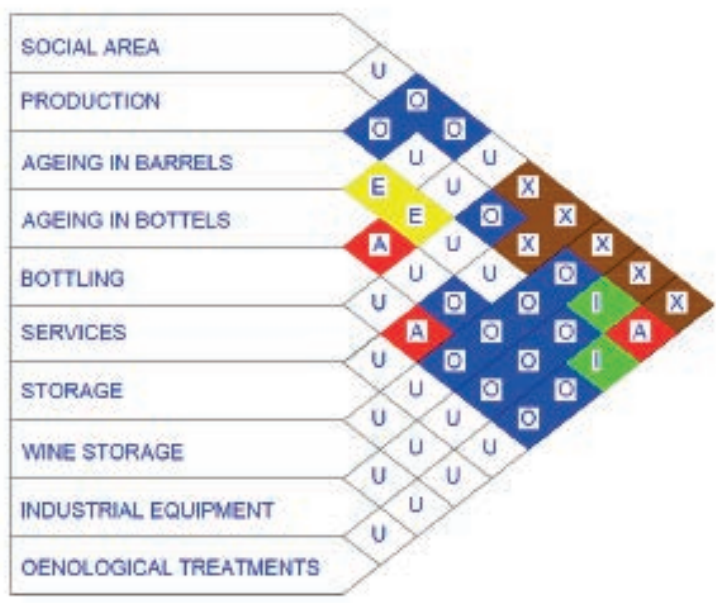

Figure 4. Relationship diagram for Class $\mathrm{C}$ wineries. 
passageways. In contrast, the diagrams for Class $A$, Class $B-1$ and Class $B-2$ were the same and excluded the three functional units mentioned above. The closeness/farness demands between the functional units included in each diagram were assumed identical; they did not depend on winery class. Therefore, the relationship diagram for Class $C$ wineries is the most complete of the four diagrams built up and can be considered as the standard relationship diagram for Rioja wineries.

Figure 5 shows type layouts for the different classes of winery, as derived from the SLP treatment of the information collected for each. The mean surface areas devoted to the different functional units were used in each case. In addition, the main flows of the production process among the functional units (raw material, intermediate products, finished product and by-products) have been included in the figure. These flows correspond to the production of aged red wine, which represents $56 \%$ of the total quantity of Rioja wine commercialised per year (Control Board of the Rioja Designation of Origin, 2016); they would be slightly different for young red and white wines. In the case of the Class $A$ layout, the possibility of selling young wine in bulk has also been indicated,

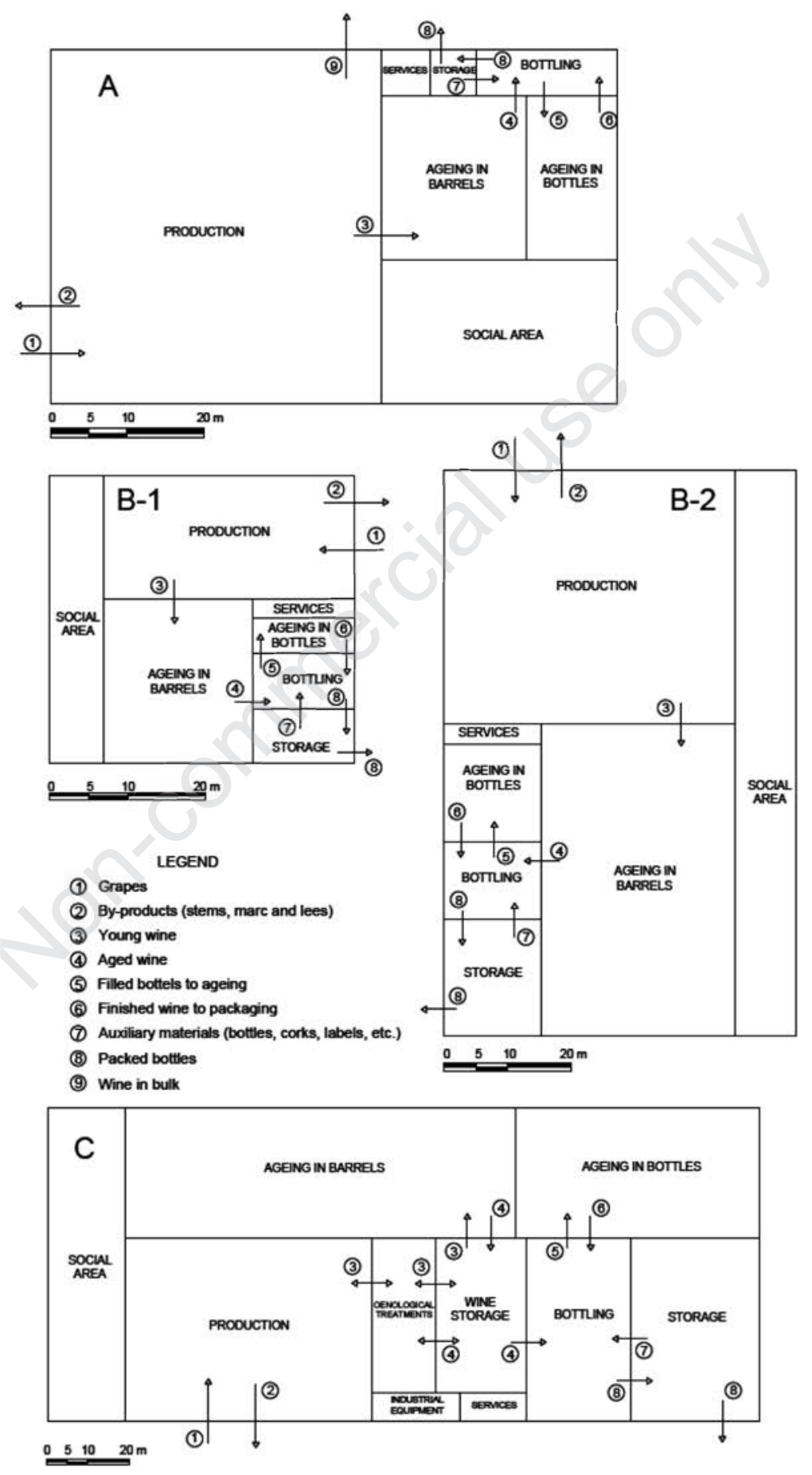

Figure 5. Proposed plant layouts for the different classes of winery. 
since that is usually the main activity of cooperative wineries. As explained above, the wine storage, oenological treatments and industrial equipment functional units were included only in the Class $C$ layout. For the rest of layouts, the set of operations corresponding to such functional units should be integrated in the spaces devoted to the production, ageing or bottling units, as normally occurs in most wineries. Also, movable devices and equipments are often used in different areas of wineries.

The type layouts were obtained taking into account the design factors and constraints mentioned in Section Analysis of winery layouts. Because of the large size of the ageing rooms, it was not possible to locate these units in the core of the buildings, contrary to what would have been desirable for thermal insulation and climate control system efficiency. As a result, the ageing rooms have at least one exterior wall, excepting the ageing in barrels unit in the Class A layout. In contrast, the social area units were located with two or three external walls in all cases, allowing natural lighting and facilitating the design of entrances for visitors and facades of high aesthetic quality. The social area units were separated from the eminently industrial functional units, such as the storage, oenological treatments and services units, and were located close to the ageing in barrels and production rooms in order to facilitate tour itineraries. The bottling, services and storage units were conceived as spaces that require natural lighting and ventilation. In addition, the storage unit also needs external doors that allow the movement of materials and finished product in and out.

It is important to remark that the layouts presented in Figure 5 have been defined assuming a single-level building. However, underground cellars are built in some cases, as they provide optimal environmental conditions for wine ageing (Martin and Canas, 2006). Where topography allows, building of ageing and storage rooms under the production areas can take advantage of both gravity and favourable underground thermal conditions (Torreggiani et al., 2011). In such cases, the type layouts and the corresponding flows shown in Figure 5 should be rearranged.

These type layouts could be of help in different winery design projects, though each would have its own needs and conditioning factors, such as orientation, location, geotechnical characteristics, degree of automation, temporal nature of the raw materials, type of final product, need for future expansion, etc. The practical use of these layouts would also need to take into account factors such as natural or artificial lighting, the size of passageways, ceiling height, the position of doorways and power points, etc. However, they could be used to aid in the design of wineries of different dimensions and in different geographical areas, including the design of buildings that make use of different construction materials, have different architectural components, and solve technical problems in different ways.

\section{Conclusions}

This study examines 62 industrial and cooperative wineries in the Rioja winemaking region, one of the most important in Spain. The information collected revealed the production process followed and the functional units required by each, and allowed the identification of four classes of winery. The relative surface area given over to each functional unit was determined for each winery class, and differences detected and explained. Finally, type layouts for each winery class were established using the SLP method. These could be of assistance in optimising the design of wineries, improving the efficiency and sustainability of the winemaking industry.
Determining key performance indicators in the food and beverage industry sector, such as production costs, labour inputs, energy demand, initial building costs and environmental impacts, requires relevant data retrieved from existing facilities. The analysis of these indicators is of growing interest worldwide and might be crucial for securing long-term success in the wine market. Winery design and layout can have an important influence on the above indicators. The present study offers additional information on plant layout design to researchers and winery designers.

This study also shows the importance of considering architectural quality, wine tourism and the historical background when analysing the design of these buildings. This is a remarkable difference with respect to other types of food industry facilities.

\section{References}

Barbaresi A., Dallacasa F., Torreggiani D., Tassinari P. 2017a. Retrofit interventions in non-conditioned rooms: Calibration of an assessment method on a farm winery. J. Build. Perform. Simu. 10:91-104.

Barbaresi A., Torreggiani D., Tinti F., Tassinari P. 2017b. Analysis of the thermal loads required by a small-medium sized winery in the Mediterranean area. J. Agricult. Eng. 48:9-20.

Catalano P. 1999. Effluents from wine processing. In: F.W. BakkerArkema (ed.) CIGR handbook of agricultural engineering. ASABE, St. Joseph, MI, USA, 4:483-97.

Control Board of the Rioja Designation of Origin. 2016. 2015 Annual Report. Logroño (La Rioja), Spain. Available from: http://es.riojawine.com/multimedia/files/publicaciones/Annua 1_report_Rioja_2015.pdf

Donnelly D.M. 1977. Airborne microbial contamination in a winery bottling room. Am. J. Enol. Viticult. 28:176-81.

European Commission, 2017. 'E-bacchus' database. Available from: http://ec.europa.eu/agriculture/markets/wine/e-bacchus/

Herath I., Green S., Singh R., Horne D., van der Zijpp S., Clothier B. 2013. Water footprinting of agricultural products: a hydrological assessment for the water footprint of New Zealand's wines. J. Clean. Prod. 41:232-43.

Huang C., Wong C.K. 2017. Discretized cell modeling for optimal facility layout plans of unequal and irregular facilities. J. Constr. Eng. M. 143.

Institut Technique de la Vigne et du Vin, 2013. Hygiène en oenologie: nettoyage, désinfection, HACCP. Dunod, Malakoff, France.

Jacquet P. 1999. Installations vinicoles et d'embouteillage, Vol. 1, Conception et réglementation. Feret, Bordeaux, France.

Jeong J.S., García-Moruno L., Hernández-Blanco J. 2012. Integrating buildings into a rural landscape using a multi-criteria spatial decision analysis in GIS-enabled web environment. Biosyst. Eng. 112:82-92.

Larreina M., Gómez-Bezares F., Aguado R. 2011. Development rooted on Riojan soil: the wine cluster and beyond. Open Geogr. J. 4:3-15.

Liggett R.S. 2000. Automated facilities layout: past, present and future. Automat. Constr. 9:197-215.

López M., Gómez J. 2008. Análisis comparativo, descripción de áreas funcionales y análisis de costes de implantación de bodega acogida a la D.O.Ca. Rioja y bodega no acogida a dicha reglamentación [Comparative analysis, description of functional areas and building costs of both a Rioja winery and a non-Rioja winery]. Proc. 6th Foro Mundial del Vino, Logroño, 
Spain, p. 70.

Martin S., Canas I. 2006. A comparison between underground wine cellars and aboveground storage for the aging of Spanish wines. T. ASABE 49:1471-8.

Martínez-Rodríguez A.J., Carrascosa A.V. 2009. HACCP to control microbial safety hazards during winemaking: Ochratoxin A. Food Control 20:469-75.

Muther R. 1961. Systematic layout planning. Industrial Education Institute, Boston, MA, USA.

Rugani B., Vázquez-Rowe I., Benedetto G., Benetto E. 2013. A comprehensive review of carbon footprint analysis as an extended environmental indicator in the wine sector. J. Clean. Prod. 54:61-77.

Stanwick S., Fowlow L. 2006. Wine by design. John Wiley \& Sons, Hoboken, NJ, USA.

Storm D.R. 1997. Winery utilities: planning, design and operation. Chapman and Hall, London, UK

Tassinari P., Torreggiani D., Benni S., Dall'Ara E. 2013.
Landscape quality in farmyard design: an approach for Italian wine farms. Landscape Res. 38:729-49.

Torreggiani D., Benni S., Corzani V., Tassinari P., Galassi S. 2011. A meta-design approach to agroindustrial buildings: a case study for typical Italian wine productions. Land Use Policy 28:11-8.

Torreggiani D., Benni S., Garcia A.I., Ayuga F., Tassinari P. 2014. Farm winery layout design: Size analysis of base spatial units in an Italian study area. T. ASABE 57:625-33.

Torreggiani D., Corzani V., Benni S., Tassinari P. 2013. Design of farm winery facades for the optimisation of indoor natural lighting: a case study. J. Agricult. Eng. 44:17-21.

Van Donk D.P., Gaalman G. 2004. Food safety and hygiene: systematic layout planning of food processes. Chem. Eng. Res. Des. 82:1485-93.

Vollmann T.E., Buffa E.S. 1966. The facilities layout problem in perspective. Manage. Sci. 12:450-68. 